
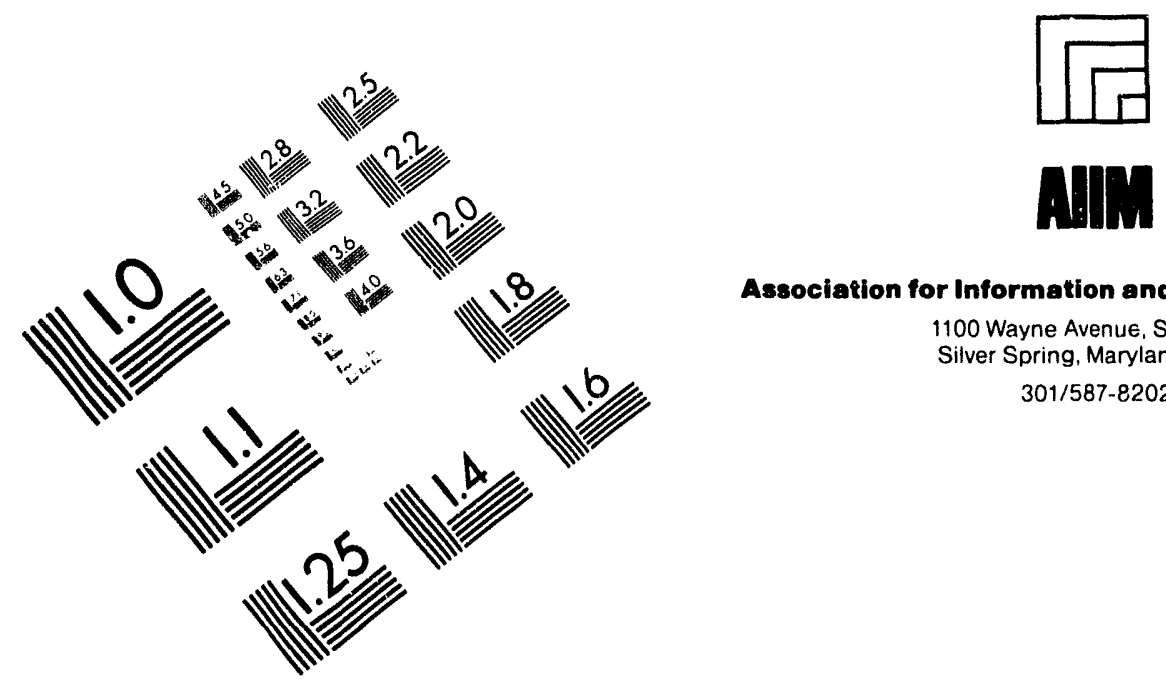

Association for Information and Image Management

1100 Wayne Avenue, Suite 1100

Silver Spring, Maryland 20910

301/587-8202

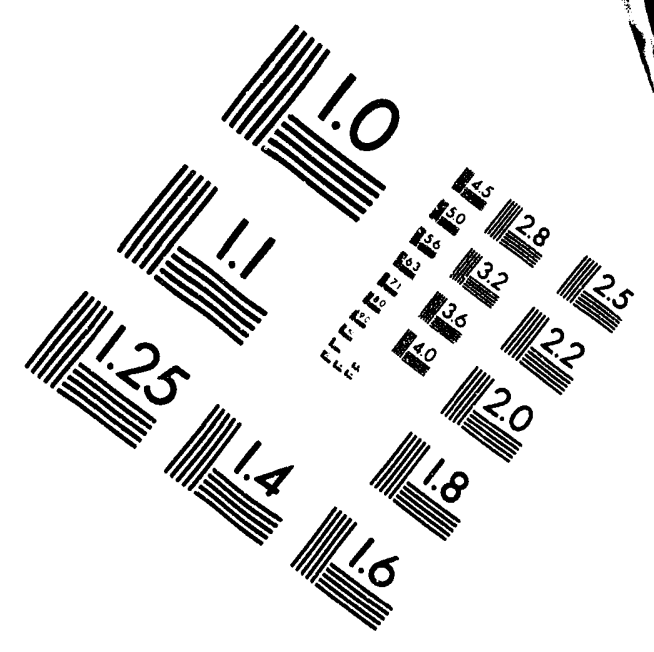

Centimeter

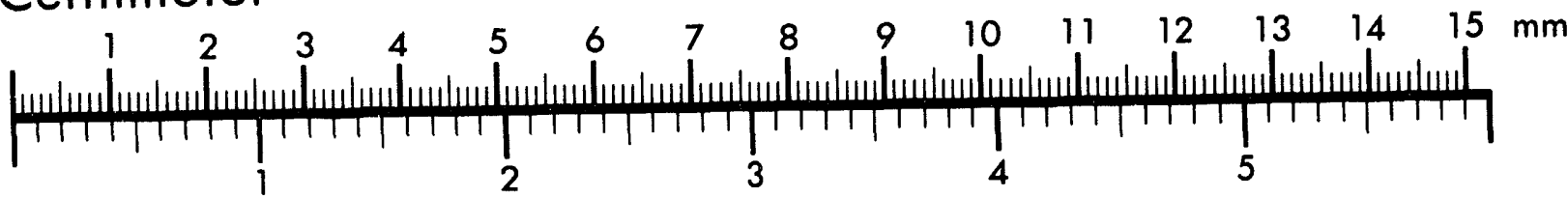
Inches
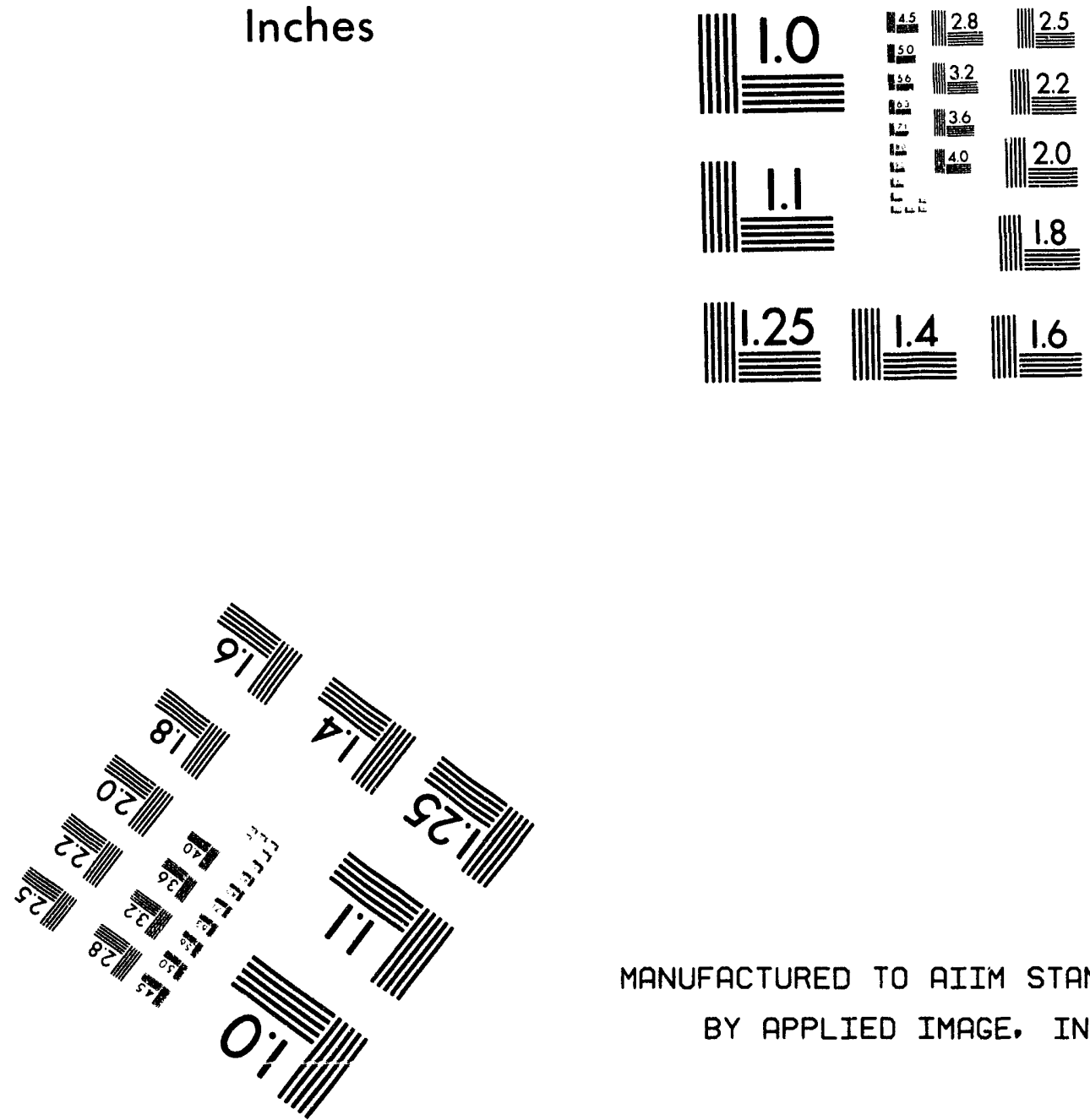

MANUFACTURED TO AIIM STANDARDS

BY APPLIED IMAGE. INC.

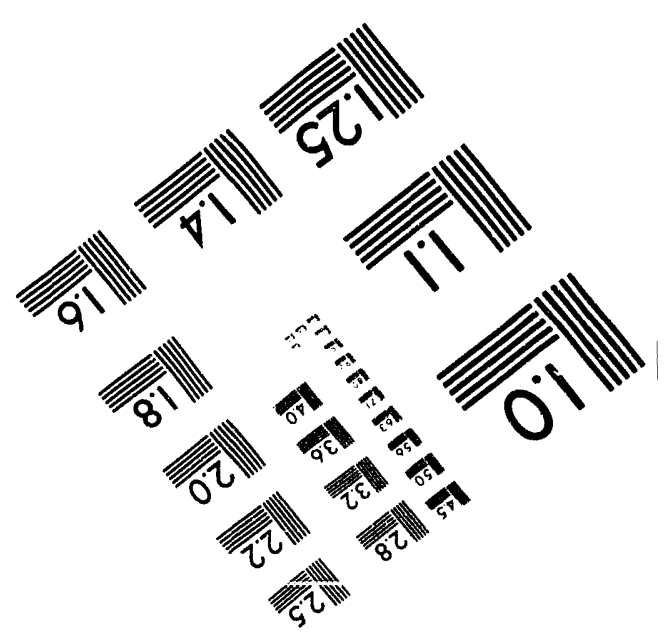



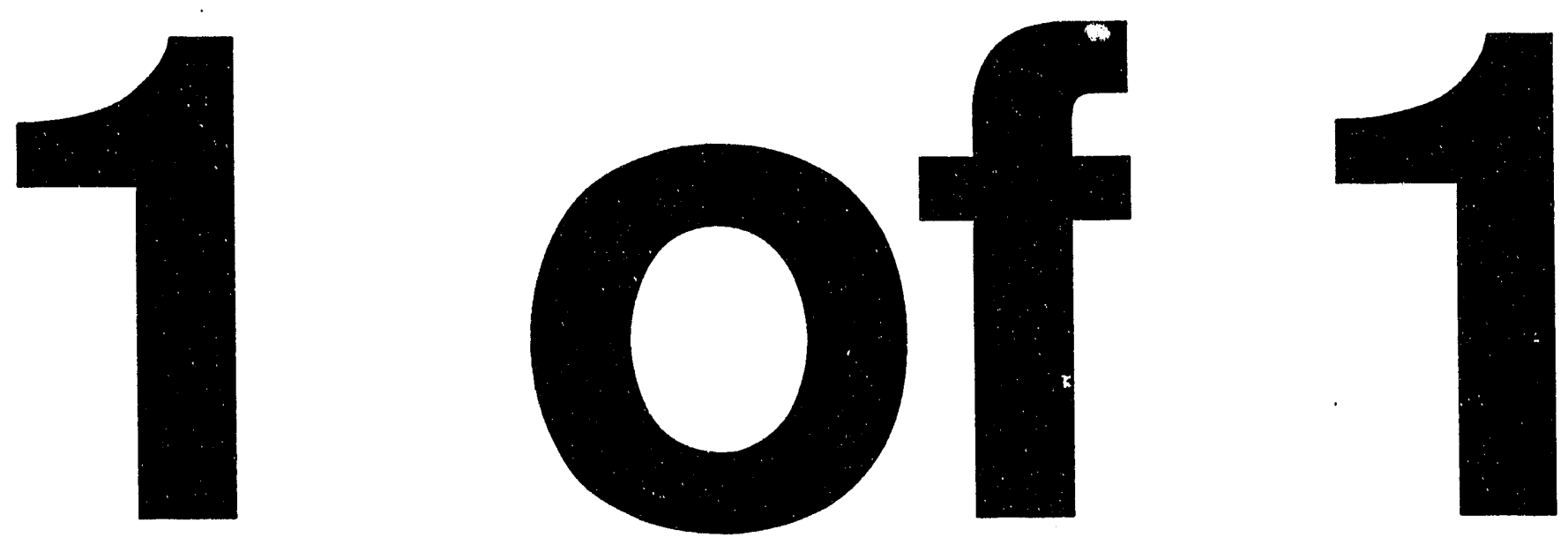


\title{
DOE/PC/9.2246--T2
}

Technical Progress Report

$28+193$

Second Quarter

(January 1, 1993 to March 31, 1993)

\section{DEVELOPMENT OF ENHANCED SULFUR REJECTION PROCESSES}

\author{
by
}

\author{
R.-H. Yoon, G. Luttrell, G. Adel and P.E. Richardson \\ Center for Coal and Minerals Processing \\ Virginia Polytechnic Institute and State University \\ Blacksburg, Virginia 24021-0258
}

Contract No.: DE-AC22-92PC92246

\section{DISCLAIMER}

\begin{abstract}
This report was prepared as an account of work sponsored by an aget y of the United States Government. Neither the United States Government nor any agency thereof, nor any of their employees, makes any warranty, express or implied, or assumes any legal liability or responsibility for the accuracy, completeness, or usefulness of any inform? tion, apparatus, product, or process disclosed, or represents that its use would not infringe privately owned rights. Reference herein to any specific commercial product, process, or service by trade name, trademark, manufacturer, or otherwise does not necessarily constitute or imply its endorsement, recommendation, or favoring by the United States Government or any agency thereof. The views and opinions of authors expressed herein do not necessarily state or reflect those of the United States Government or any agency thereof.
\end{abstract}

\section{Prepared for:}

U.S. Department of Energy

Pittsburgh Energy Technology Center

P.O. Box 10940

Pittsburgh, PA 15236-0940

June 14, 1993

Contracting officer's representative: Richard Read

U.S./DOE Pateht Clearance is not required prior to the publication of this document. 


\begin{abstract}
Research at Virginia Tech led to the development of two complementary concepts for improving the removal of inorganic sulfur from many eastern U.S. coals. These concepts are referred to as Electrochemically Enhanced Sulfur Rejection (EESR) and Polymer Enhanced Sulfur Rejection (PESR). The EESR process uses electrochemical techniques to suppress the formation of hydrophobic oxidation products believed to be responsible for the floatability of coal pyrite. The PESR process uses polymeric reagents that react with pyrite and convert floatable middlings, i.e., composite particles composed of pyrite with coal inclusions, into hydrophilic particles. These new pyritic-sulfur rejection processes do not require significant modifications to existing coal preparation facilities, thereby enhancing their adoptability by the coal industry. It is believed that these processes can be used simultaneously to maximize the rejection of both well-liberated pyrite and composite coal-pyrite particles.

The technical research was initiated on October 1, 1992, and a detailed work plan and work schedule (Task 1) were developed. During this reporting period, research was conducted to evaluate the liberation characteristics of various pyrite samples (Task 2), to determine the electrochemical reactions that influence the hydrophobicity of pyrite (Task 3 ), and to examine the potential use of electrochemical methods for controlling the flotation and depression of pyrite (Task 5).
\end{abstract}




\section{TAB' I OF CONTENTS}

ABSTRACT $\ldots \ldots \ldots \ldots \ldots \ldots \ldots \ldots \ldots \ldots \ldots$ i

TABLE OF CONTENTS $\ldots \ldots \ldots \ldots \ldots \ldots \ldots$ ii

LIST OF FIGURES $\ldots \ldots \ldots \ldots \ldots \ldots \ldots \ldots \ldots \ldots$ iii

LIST OF TABLES $\ldots \ldots \ldots \ldots \ldots \ldots \ldots \ldots \ldots \ldots$ iv

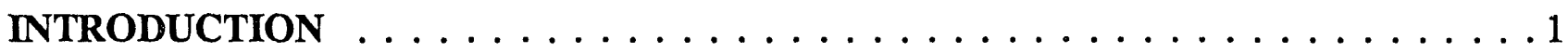

OBJECTIVES DURING THIS REPORTING PERIOD $\ldots \ldots \ldots \ldots \ldots$

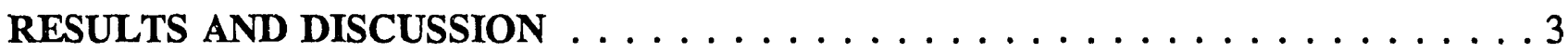

Task 1 - Project Planning $\ldots \ldots \ldots \ldots \ldots \ldots \ldots \ldots$

Task 2 - Characterization . . . . . . . . . . . . . . . . 3

2.1 Coal Samples and Characterization $\ldots \ldots \ldots \ldots \ldots \ldots$

Task 3 - Electrochemical Studies . . . . . . . . . . . . . . . . 7

3.1 Linear Voltammetric Sweeps . . . . . . . . . . . . 7

3.2 Determination of Reducing Potentials . . . . . . . . . 8

3.3 Mechanisms/Kinetics of Pyrite Oxidation by Cyclic

Voltammetry . . . . . . . . . . . . . . 9

Task 4 - In-Situ Monitoring of Reagent Adsorption on Pyrite . . . . . . . . . 12

$\underline{4.1}$ Mechanistic Studies of Reagent Adsorption on Pyrite . . . . . . 12

4.2 Contact Angle Measurements of Reagents on Pyrite

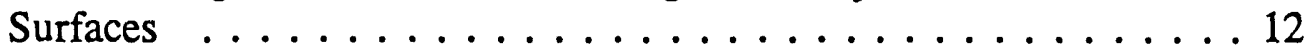

Task 5 - Bench Scale Testing of the EESR Process . . . . . . . . . . . 12

5.1 Microflotation Tests . . . . . . . . . . . . . 12

$\underline{5.2}$ Galvanic Control Using Metal and Alloy Powders . . . . . . . 15

$\underline{5.3}$ Galvanic Control Using Sacrificial Anodes . . . . . . . . 16

Task 6 - Bench Scale Testing of the PESR Process . . . . . . . . . . . 16

Task 7 - Modelling and Simulation $\ldots \ldots \ldots \ldots \ldots \ldots$

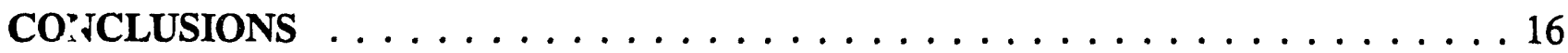

ACTIVITIES PLANNED FOR NEXT QUARTER $\ldots \ldots \ldots \ldots \ldots$ 


\section{LIST OF FIGURES}

Figure 1: $\quad$ Voltammograms on Chinese coal pyrite at $\mathrm{pH} 9.2$ in the absence and presence of $\mathrm{FeCl}_{2}$ (top). Ring current (bottom) observed with the ring held at $0.25 \mathrm{~V}$ during the potential sweeps on the pyrite disc electrode $\ldots \ldots \ldots \ldots$. . . . . . . . . . . 10

Figure 2: $\quad$ Voltammogram on a mineral pyrite disc electrode (top); subsequent voltammograms (middle and bottom) on the gold ring after soluble dissolution products produced on the disc are deposited on the ring. The middle voltammogram was obtained after the potential on the disc was stopped at $-0.32 \mathrm{~V}$ during the second cathodic sweep; the bottom voltammogram was obtained on the ring after the potential on the disc was stopped at $-0.45 \mathrm{~V}$ during the second anodic scan. The ring potential was held at $0.25 \mathrm{~V}$

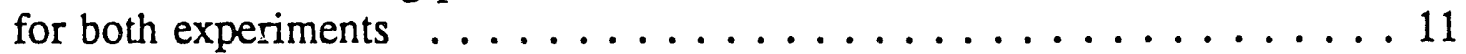

Figure 3: $\quad$ Pyrite recovery versus the potential of a pyrite electrode at several $\mathrm{pH}$ values. Hydrazine, permanganate, and sodium sulfide were used to vary the potential . . . . . . . . . . . . . . 13

Figure 4: Potential of a bright platinum electrode versus the potential of a mineral pyrite electrode, both inserted into the top of the micro-flotation cell. Hydrazine, permanganate, and sodium sulfide were used to vary the potential .............. 15 


\section{LIST OF TABLES}

Table 1. Size distribution for -28 mesh Pittsburgh No. 8 coal $\ldots \ldots \ldots$

Table 2. Size distribution for -28 mesh Illinois No. 6 coal $\ldots \ldots \ldots$

Table 3. Size distribution for -100 mesh Pittsburgh No. 8 coal $\ldots \ldots \ldots$

Table 4. Size distribution for -100 mesh nlinois No. 6 coal . . . . . . . . . 6

Table 5. Size distribution for -400 mesh Pittsburgh No. 8 coal . . . . . . . 6

Table 6. Size distribution for -400 mesh 11 linois No. 6 coal . . . . . . . . . 6

Table 7. Microflotation test results for fresh $75 \times 150 \mu \mathrm{m}$ Illinois

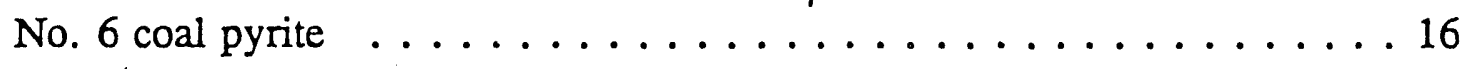




\section{INTRODUCTION}

Recent work at the Center for Coal and Minerals Processing identified two major reasons why even the most advanced coal cleaning technologies (without fine grinding) fail to meet what is normally a standard flotation separation for most mineral systems, i.e., a 90-95\% rejection of pyrite from coal. They are the:

i) superficial oxidation of pyrite as an inadvertent corrosion-type process occurring during mining and processing, and

ii) incomplete liberation of pyrite from coal causing a large fraction of the pyrite to remain associated or locked with the coal as middlings.

The superficial oxidation produces a surface layer on pyrite composed of excess sulfur (or polysulfides), which is inherently hydrophobic. Thus, even fully-liberated pyrite when superficially oxidized can show a flotation response similar to that of coal, making the separation difficult. Furthermore, the incomplete liberation of pyrite from coal creates coal/pyrite composites which behave more like coal during flotation. Even small inclusions of coal in pyrite particles can render the composite particles floatable.

Research at Virginia Tech's Center for Cual and Mineral Processing (CCMP) suggests two solutions to these problems, i.e., Electrochemically-Enhanced Sulfur Rejection (EESR) and Polymer-Enhanced Sulfur Rejection (PESR) processes. The EESR concept is a novel technique that prevents the superficial oxidation of pyrite without using traditional reducing reagents. It uses sacrificial anodes to prevent the oxidation of pyrite and, hence, minimizes the formation of hydrophobic oxidation products. This technique is flexible enough to be implemented during the process of grinding, conditioning, or flotation. The PESR process is based on synthesizing 
polymeric organic reagents whose functional groups react with pyrite, possibly via an electrochemical mechanism, while the hydrophilic polymer chains are stretched over the coal inclusions, rendering the pyrite-coal composite particles nonfloatable. The EESR and PESR processes are complementary since the former suppresses the flotation of well-liberated pyrite, while the latter suppresses the flotation of middlings.

The overall objective of this research is to develop these processes into technologies for improving the rejection of pyritic sulfur from eastern U.S. coals. If successful, a high degree of pyritic sulfur rejection could be achieved without having to micronize coal.

\section{OBJECTIVES DURING THIS REPORTING PERIOD}

Following are the overall objectives of the research effort carried out during the second reporting period:

- to continue electrochemical studies to determine if the source of coal pyrite effects either the mechanism or the kinetics of oxygen reduction,

- to continue studies of the mechanisms of pyrite oxidation by cyclic voltammetry and determine if the kinetics of pyrite oxidation depends on the source of pyrite,

- to conduct microflotation tests to study the effect of controlling the electrochemical potential on flotation, and

- to investigate the use of reactive metal powders as sacrificial anodes to minimize pyrite oxidation and enhance pyrite rejection.

Research was carried out according to the work plan on each of these tasks. For this report, the terminology "coal pyrite" and "mineral pyrite" refer to pyrite derived from coal and non-coal sources, respectively. 


\section{RESULTS AND DISCUSSION}

Task 2 - Characterization

Subtask 2.1: - Coal Samples and Characterization

During the past quarter, two 200-liter containers of run-of-mine Pittsburgh No. 8 and Illinois No. 6 coal were obtained from northern West Virginia and southern Illinois, respectively. Upon arrival, the samples were spread out and allowed to dry at ambient temperature to remove excess surface moisture. The dried samples were then crushed in a laboratory jaw crusher followed by a roll crusher to produce a $-6 \mathrm{~mm}$ product for storage. Representative samples of $-6 \mathrm{~mm}$ material were collected for each of the two coals and subjected to analysis for moisture, ash, volatile matter, fixed carbon, total sulfur, pyritic sulfur, organic sulfur and calorific value. The results of this analysis are still pending.

The remaining material was further reduced to produce the three size fractions (i.e., -28 mesh, -100 mesh and -400 mesh) required for this project. The -28 mesh fraction was produced from the $-6 \mathrm{~mm}$ material by using a roll crusher in closed-circuit with a 28 mesh screen. The closed circuit arrangement was used to minimize the production of fines. Similarly, the -100 mesh fraction was prepared from the $-6 \mathrm{~mm}$ material using a laboratory hammer mill containing a 100 mesh screen. Finally, the -400 mesh fraction was prepared from the -100 mesh material by wet grinding in a laboratory batch ball mill. The mill was operated in locked-cycle with a 400 mesh screen to prevent overgrinding and to ensure that the 400 mesh top size of the final product was maintained. The final size distributions for each of the three size fractions, as determined by wet screening, are shown in Tables 1-6. As shown, all samples are in the range of $90-95 \%$ passing the stated size as specified in the Project Work Plan. 
At the present time, six release analysis tests have been completed on the -28 mesh fraction for both coal samples. The tests were conducted in triplicate to ensure the accuracy of the data. The results of these tests are currently unavailable pending analysis of the release analysis products. In addition, sample briquettes have been prepared for all nine size classes of the -28 mesh fraction shown in Tables 1 and 2 . These briquettes will be analyzed using the SEM-IPS image analyzer as part of Task 2.2. Finally, centrifuge vials are currently being prepared so that centrifugal float-sink tests can be carried out on each of the size fractions for both coal samples.

During the next quarter, it is expected that release analysis tests vill be completed on the -100 and -400 mesh fractions for both coals and all analyses will be available in the next quarterly report. It is also expected that centrifugal float sink tests will be well underway although probably not completed. Considering the test work remaining on the present two coals and the need to conduct these same tests on a third coal which has yet to be obtained, it is estimated that all work in Subtask 2.1 will be completed by the end of the fourth quarter. 
Table 1. Size distribution for -28 mesh Pittsburgh No. 8 coal.

\begin{tabular}{|c|r|r|}
\hline Size Class (Mesh) & Wt. \% in Class & Wt. \% Passing \\
\hline $28 \times 35$ & 28.06 & 100.00 \\
\hline $35 \times 48$ & 19.17 & 71.94 \\
\hline $48 \times 65$ & 14.33 & 52.77 \\
\hline $65 \times 100$ & 9.91 & 38.44 \\
\hline $100 \times 150$ & 9.09 & 28.53 \\
\hline $150 \times 200$ & 5.25 & 19.44 \\
\hline $200 \times 270$ & 3.85 & 14.19 \\
\hline $270 \times 400$ & 2.71 & 10.34 \\
\hline-400 & 7.63 & 7.63 \\
\hline
\end{tabular}

Table 2. Size distribution for -28 mesh Illinois No. 6 coal.

\begin{tabular}{||r|r|r||}
\hline Size Class (Mesh) & Wt. \% in Class & \multicolumn{1}{|c|}{ Wt. \% Passing } \\
\hline \hline $28 \times 35$ & 27.40 & 100.00 \\
\hline $35 \times 48$ & 18.27 & 72.60 \\
\hline $48 \times 65$ & 11.53 & 54.33 \\
\hline $65 \times 100$ & 11.21 & 42.80 \\
\hline $100 \times 150$ & 5.85 & 31.59 \\
\hline $150 \times 200$ & 5.97 & 25.74 \\
\hline $200 \times 270$ & 3.71 & 19.77 \\
\hline $270 \times 400$ & 2.26 & 16.06 \\
\hline-400 & 13.80 & 13.80 \\
\hline
\end{tabular}


Table 3. Size distribution for -100 mesh Pittsburgh No. 8 coal.

\begin{tabular}{||r|r|r|}
\hline Size Class (Mesh) & Wt. \% in Class & \multicolumn{1}{|c|}{ Wt. \% Passing } \\
\hline+100 & 4.20 & 10000 \\
\hline $100 \times 150$ & 8.98 & 95.80 \\
\hline $150 \times 200$ & 13.86 & 86.82 \\
\hline $200 \times 270$ & 15.52 & 72.96 \\
\hline $270 \times 400$ & 13.18 & 57.44 \\
\hline-400 & 44.26 & 44.26 \\
\hline
\end{tabular}

Table 4. Size distribution for -100 mesh Illinois No. 6 coal.

\begin{tabular}{||r|r|r||}
\hline Size Class (Mesh) & Wt. \% in Class & \multicolumn{1}{|c|}{ Wt. \% Passing } \\
\hline+100 & 9.28 & 100.00 \\
\hline $100 \times 150$ & 16.88 & 90.72 \\
\hline $150 \times 200$ & 13.99 & 73.84 \\
\hline $200 \times 270$ & 12.26 & 59.85 \\
\hline $270 \times 400$ & 9.98 & 47.65 \\
\hline-400 & 37.67 & 37.67 \\
\hline
\end{tabular}

Table 5. Size distribution for -400 mesh Pittsburgh No. 8 coal.

\begin{tabular}{|c|r|r|}
\hline Size Class (Mesh) & Wt. \% in Class & \multicolumn{1}{|c|}{ Wt. \% Passing } \\
\hline+400 & 5.59 & 100.00 \\
\hline-400 & 94.41 & 94.41 \\
\hline
\end{tabular}

Table 6. Size distribution for -400 mesh Illinois No. 6 coal.

\begin{tabular}{|c|r|r|}
\hline Size Class (Mesh) & Wt. \% in Class & \multicolumn{1}{|c|}{ Wt. \% Passing } \\
\hline+400 & 6.48 & 100.00 \\
\hline-400 & 93.52 & 93.52 \\
\hline
\end{tabular}


Task: 3 - Electrochemical studies

Subtask 3.1: Linear Voltanımetric Sweeps

During the first quarter of ihis project, an extensive study was completed regarding the reduction of oxygen on coal pyrite from the Pittsburgh No. 8 seam, coal pyrite from Sichuan, China, and mineral pyrite from Huanzala, Peru. Previous studies indicated significant differences in the electroactivity for oxygen reduction between the three pyrite samples. Essentially, at pH 9.2, the electrocatalytic ability of Pittsburgh No. 8 pyrite for oxygen reduction is less than that of the other two pyrites; whereas at pH 4.6 and 6.8 the Pittsburgh No. 8 pyrite shows a greater electiocatalytic ability to reduce oxygen. In addition, at $\mathrm{pH} 4.6$, oxygen reduction proceeds through the intermediate hydrogen peroxide on the Chinese and mineral pyrite, but proceeds all the way to $\mathrm{OH}^{-}$on the Pittsburgh No. 8 pyrite.

Further analysis of oxygen reduction on the three electrodes during this reporting period suggests that the more porous nature of the Pittsburgh No. 8 pyrite (compared to the other two pyrites) may be responsible for its different behavior. It is believed that at $\mathrm{pH} 9.2$, insoluble ferrous and ferric hydroxides may form in the pores, blocking access to dissolved oxygen and reducing the overall rate of oxygen reduction. At lower $\mathrm{pH}$ 's where the hydroxides are more soluble, oxygen is believed to be first reduced to hydrogen peroxide in the pores and then, before it escapes, the hydrogen peroxide is further reduced to $\mathrm{OH}^{-}$.

During this reporting period, several of the oxygen reduction studies were repeated and the resulting pyrite samples were prepared for analysis by X-ray Photoelectron Spectroscopy (XPS). The XPS data was needed to help explain why the reduction of oxygen on Pittsburgh No. 8 coai pyrite is much different than the reduction of oxygen on the more crystalline mineral 
pyrite and Chinese coal pyrite. Electrodes treated at the three $\mathrm{pH}$ levels were submitted for XPS analysis. The objective was to compare the quantity of hydroxides on mineral pyrite and Pittsburgh Nn. 8 pyrite samples treated at different $\mathrm{pH}$ values. This comparison may support the tentative conclusion that the porous natlire of the Pittsburgh No. 8 pyrite determines the mechanism and kinetics of oxygen reduction. Unfortunately, shortly after the samples were prepared, the XPS unit malfunctioned. The XPS unit has been fixed and new samples are being prepared for analysis. These results will be reported in an upcoming technical progress report.

\section{Subtask 3.2: Determination of Reducing Potentials}

A two compartment electrochemical cell connected by a fritted glass tube was constructed to study the effect of galvanic coupling between pyrite and reactive metal powders that can act as sacrificial anodes. Measurements have been initiated to determine galvanic coupling effects between pyrite and manganese. One interesting problem encountered in laboratory flotation cells will be addressed in this task. It was found (see Task 5.2 - Galvanic Control Using Metal and Alloy Powders) that the potential of platinum electrodes inserted in laboratory flotation cells is sometimes different than that of a pyrite electrode. The platinum acts as a redox electrode in which the reversible potentiai of the dominant redox couple in solution is measured. For example, if ferrous and ferric ions are present, the platinum measures the Nernst potential,

$$
E_{h}=E^{0}-[0.059 / n] \ln \left[F^{2+}\right] /\left[F e^{3+}\right]
$$

and does not undergo a reaction itself. However, pyrite appears to undergo a surface reaction that inhibits changes in electrode potential. It has also been observed that the potential of coal pyrite does not change as much as the potential of mineral pyrite when redox reagents are added 
to the cell. This is believed to be related to the high reactivity of coal pyrite which again prevents the potential of coal pyrite from changing.

With regard to flotation, it is the potential of the pyrite itself that should control selfinduced flotation. It is therefore necessary to determine the factors which control the potential of pyrite as opposed to the redox potential of the solution phase.

Subtask 3.3: Mechanism/Kinetics of Pyrite Oxidation by Cyclic Voltammetry

During the first reporting period, extensive ring-disc electrode studies were conducted to investigate the mechanism and kinetics of the oxidation of two cral pyrites and one mineral pyrite. One of the most interesting aspects of this research was the observation of three soluble reaction products on pyrite at $\mathrm{pH}$ 9.2. One of these products was attributed to HS. HS- is produced at negative potentials on the cyclic voltammetry curves and can then be reoxidized on the gold ring held at more positive potentials. The other two products were attributed to a soluble ferrous hydroxide species. The soluble ferrous hydroxide was produced by 1) reduction of $\mathrm{Fe}(\mathrm{OH})_{3}$ that was formed by prior anodic oxidation and 2) by the oxidation of elemental iron that was formed on the electrode by prior reduction of pyrite at negative potentials. The soluble ferrous hydroxide species has not been reported previously.

During this reporting period, the effect of ferrous chloride on the disc voltammograms and the ring currents were determined. As shown in Figure 1, the addition of $\mathrm{Fe}^{2+}$ significantly increased the cathodic peak on the disc voltammograms at $-0.32 \mathrm{~V}$. This increase confirms the suggestion that part of the peak results from the reduction of ferric compounds. A second cathodic peak is also resolved at $-0.65 \mathrm{~V}$, which can be attributed to the reduction of ferrous hydroxide to elemental iron. The additional ring current observed during both the cathodic and 


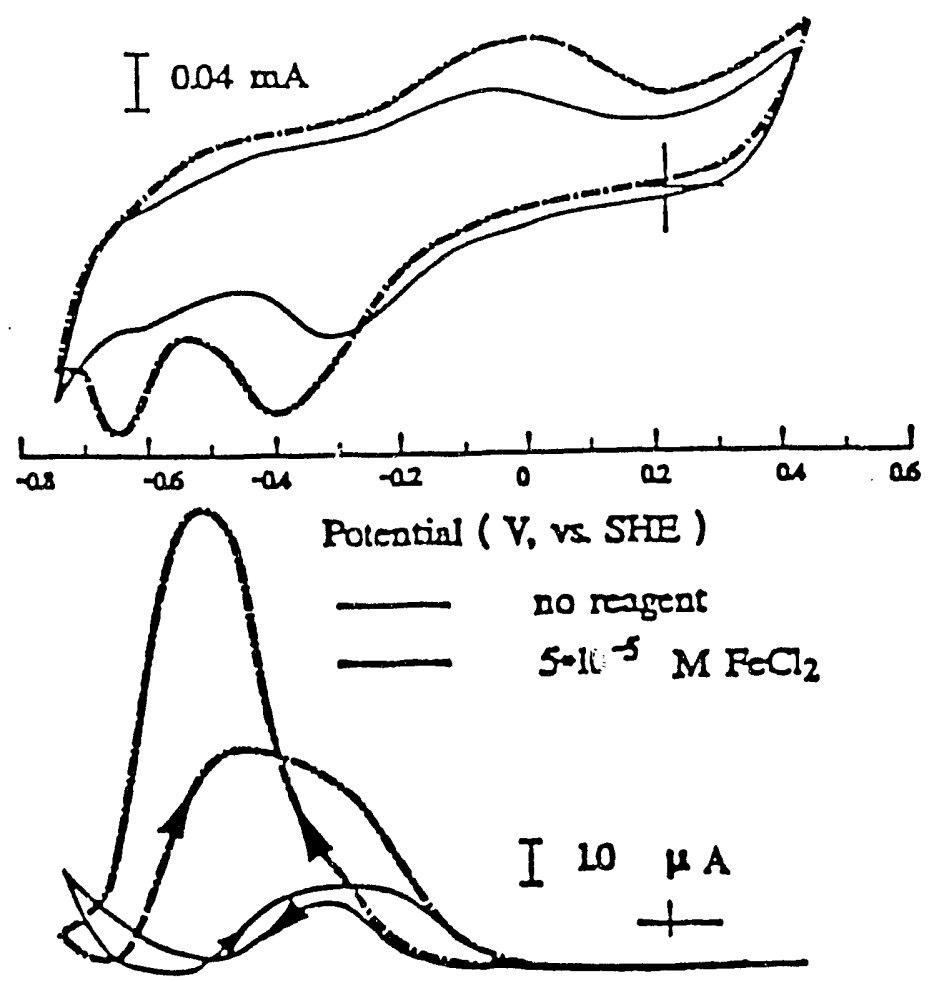

Figure 1: Voltammograms on Chinese coal pyrite at $\mathrm{pH} 9.2$ in the absence and presence of $\mathrm{FeCl}_{2}$ (top). Ring current (bottom) observed with the ring held at $0.25 \mathrm{~V}$ during the potential sweeps on the pyrite disc electrode.

anodic sweeps indicates that the addition of $\mathrm{Fe}^{2+}$ leads to an increase in $\mathrm{Fe}(\mathrm{OH})_{3}$ during the anodic sweep at potentials near 0 V (apparent on the voltammogram), and a subsequent increase in the concentration of soluble ferrous hydroxide produced during the cathodic sweep (also evident on the voltammogram). The addition of $\mathrm{Fe}^{2+}$ also increased the ring current during the subsequent anodic scan. This finding indicates that a larger amount of elemental iron is produced at the negative potential limit which can then be oxidized to form the soluble ferrous hydroxide species.

It is expected that the gold ring may have adsorbed compounds very similar to those formed on pyrite. When holding the ring at $0.25 \mathrm{~V}$ during potential scans on the disc between approximately 0.5 to $-0.75 \mathrm{~V}$, both $\mathrm{Fe}(\mathrm{OH})_{3}$ and $\mathrm{S}^{\circ}$ may be deposited on the ring. During reduction on the negative potential scan, these may react to form an iron sulfide. To confirm that both soluble and insoluble iron and sulfur compounds are produced during the potential scans, the potential on the disc was interrupted at various potentials and voltammetry curves for 


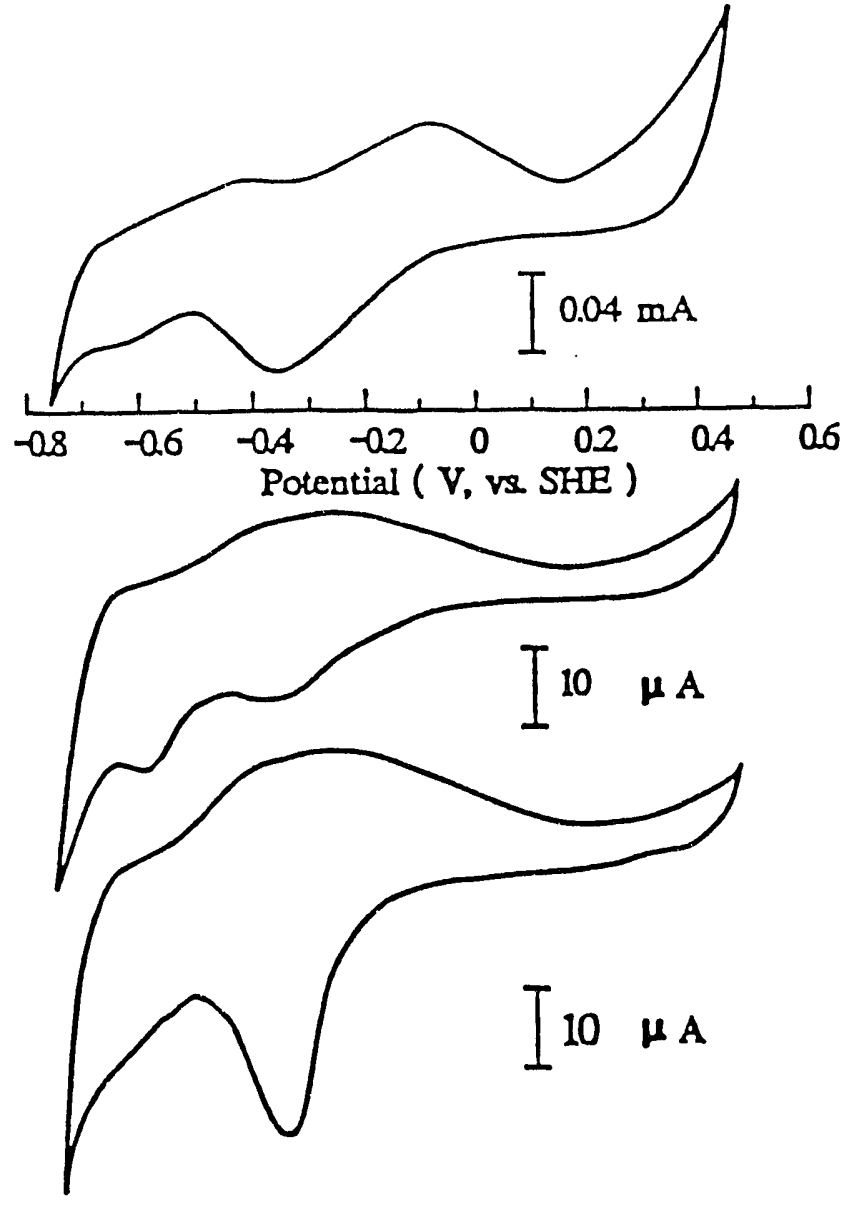

Figure 2: Voltammogram on a mineral pyrite disc electrode (top); subsequent voltammograms (middle and bottom) on the gold ring after soluble dissolution products produced on the disc are deposited on the ring. The middle voltammogram was obtained after the potential on the disc was stopped at $-0.32 \mathrm{~V}$ during the second cathodic sweep; the bottom voltammogram was obtained on the ring after the potential on the dise was stopped at $-0.45 \mathrm{~V}$ during the second anodic scan. The ring was potential was held at $0.25 \mathrm{~V}$ for both experiments. the rings were obtained. Figure 2 (top) shows the second sweep voltammogram for a mineral pyrite disc electrode. The middle curve shows a voltammogram obtained on the gold ring when the ring was held at $0.25 \mathrm{~V}$ and the potential sweep on the disc was interrupted at $-0.32 \mathrm{~V}$ during the second cathodic scan. This procedure should have produced both $\mathrm{Fe}(\mathrm{OH})_{3}$ and an oxidation product of HS on the ring. The presence of two cathodic peaks at $-0.32 \mathrm{~V}$ and $-0.55 \mathrm{~V}$ is in agreement with this expectation. The bottom curv: in Figure 2 shows the voltammetry curve obtained using the ring electrode when the ring was held at 0.25 and the disc sweep was interrupted at $-0.45 \mathrm{~V}$ during the second potential sweep. This should have produced a surface with a large amount of $\mathrm{Fe}(\mathrm{OH})_{3}$, consistent with the large single cathodic peak at $-0.32 \mathrm{~V}$. 
Task 4 - In Situ Monitoring of Reagent Adsorption on Pyrite

No work was scheduled during this reporting period.

Subtask 4.1 Mechanistic Studies of Reagent Adsorption on Pyrite

No work was scheduled during this reporting period.

Subtask 4.2 Contact Angle Measurements of Reagents on Pyrite Surfaces

No work was scheduled during this reporting period.

\section{Task 5 - Bench-Scale Testing of the EESR Process}

\section{Subtask 5.1 Microflotation Tests}

During this reporting period, a variety of reducing, oxidizing, and neutral reagents were evaluated for their effect on pyrite flotation. Most of the work was conducted using mineral pyrite from Peru since suitable samples of coal pyrite were difficult to obtain (this problem has now been overcome).

Flotation studies were conducted in a microflotation cell containing a glass frit for dispersing gas. The mineral pyrite was ground to $75-150 \mu \mathrm{m}$ and $0.8 \mathrm{gm}$ samples were used for flotation. Prior to flotation, the minerals were conditioned in $130 \mathrm{ml}$ of solution containing the desired reagents for ten minutes, followed by conditioning with kerosene $(0.06$ to $0.07 \mathrm{cc} / \mathrm{L})$ for two minutes, then MIBC frother for another two minutes. A gas flow rate of $35 \mathrm{cc} / \mathrm{min}$ of either air or nitrogen was employed for all experiments. Recoveries were determined after 3, 7 and 8 minutes of flotation.

The first series of tests were conducted to evaluate the effect of $\mathrm{pH}$ and electrochemical potential of the flotation liquor on the flotation of pyrite. The redox potential of the solution 


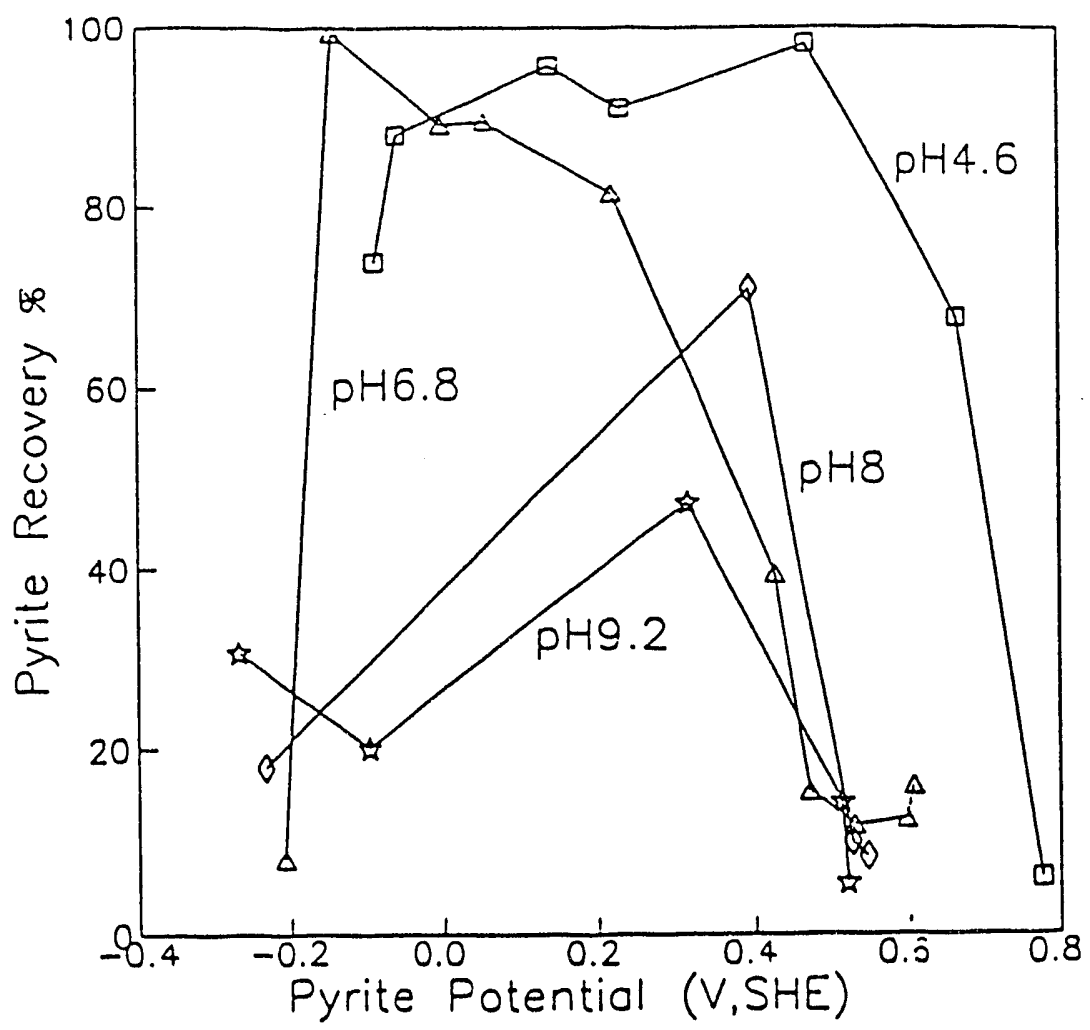

Figure 3: Pyrite recovery versus the potential of a pyrite electrode at several $\mathrm{pH}$ values. Hydrazine, permanganate, and sodium sulfide were used to vary the potential.
$\left(\mathrm{E}_{\mathrm{h}}\right)$ was measured with a platinum electrode. In addition, a pyrite electrode was used to measure the potential assumed by the mineral. Figure 3 shows recovery-potential curves at several pH's for mineral pyrite. The data has been plotted versus the potential of the pyrite electrode. Hydrazine, sodium sulfide, and potassium permanganate were used to control the potential. Hydrochloric and nitric acids were used to adjust the $\mathrm{pH}$. This work is ongoing and additional data points must be obtained to fully define the lower and upper flotation edges and the dependence of the flotation edges on $\mathrm{pH}$. However, it is clear that pyrite is strongly depressed at more oxidizing potentials and at more reducing potentials. An upper flotation edge occurs at approximately 0.5 $\mathrm{V}$ which is independent of $\mathrm{pH}$ in the range 6.8 to 9.2 . This limit shifts to higher potential values at $\mathrm{pH}$ 4.6. It is generally accepted that pyrite oxidizes by the reactions:

$$
\begin{gathered}
\mathrm{FeS}_{2}+3 \mathrm{H}_{2} \mathrm{O} \rightarrow \mathrm{Fe}(\mathrm{OH})_{3}+2 \mathrm{~S}^{\circ}+3 \mathrm{H}^{+}+3 e^{-} \\
\mathrm{FeS}_{2}+11 \mathrm{H}_{2} \mathrm{O} \rightarrow \mathrm{Fe}(\mathrm{OH})_{3}+2 \mathrm{SO}_{4}^{2-}+19 \mathrm{H}^{+}+15 e^{-}
\end{gathered}
$$


The second reaction has been written with sulfur as a product, although the actual product may be a polysulfide $\left(\mathrm{Fe}_{\mathrm{n}} \mathrm{S}, \mathrm{n}>2\right)$ or a metal-deficient pyrite $\left(\mathrm{Fe}_{(1-x)} \mathrm{S}\right)$. The relative importance of these reactions is that sulfate ion (reaction 3), rather than sulfur (reaction 2), becomes the dominant reaction with increasing anodic potentials. Thus, the depression of flotation observed at more oxidizing potentials represents a decrease in sulfur on the surface and a corresponding increase in $\mathrm{Fe}(\mathrm{OH})_{3}$. Reactions 2 and 3 suggest that the upper flotation edge shifts to more positive potentials with increasing $\mathrm{pH}$. This shift is observed from $\mathrm{pH} 4.6$ to 6.8 ; however, the upper flotation edge appears to be independent of $\mathrm{pH}$ between 6.8 and 9.2. Further studies are required to determine why the upper flotation edge is independent of $\mathrm{pH}$ in basic solutions. Similar considerations apply to the lower flotation edge; however, more data points must be obtained in the region of the lower edge.

One method to obtain information on the products of oxidation produced on pyrite in the flotation cell is to conduct linear voltammetric sweeps on the pyrite electrode used to measure the potential. The reducible species present on the surface can be determined by this method and correlated with the flotation edge and its shift with $\mathrm{pH}$. This work will be initiated during the third quarter of this project.

As a part of the flotation studies, the potential of both platinum and pyrite electrodes inserted in the flotation cell are being measured. Figure 4 shows a plot of the potential measured with a bright platinum electrode against that measured with a pyrite electrode. As mentioned above, the platinum potential represents the redox potential of the solution while the pyrite electrode represents the redox potential plus chemical changes occurring on the pyrite surface. If both electrodes measured the same potential, the plot would be a straight line passing 
through the origin with a slope of $45^{\circ}$ (as shown by the dashed line). At strongly oxidizing potentials, the platinum electrode consistently measures more positive potentials than the pyrite wectrod. This may be caused by an oxidation reaction occurring on the pyrite electrode preventing the pyrite from polarizing to the same extent as platinum.

\section{Subtask 5.2 Galvanic Control Using Metal and Alloy Powders}

Preliminary studies to galvanically control pyrite flotation were initiated using manganese powders added directly to the flotation cell. These studies used freshly ground (75 to $150 \mu \mathrm{m}$ ) Illinois No. 6 coal pyrite and $45 \mu \mathrm{m}$ manganese powder. In these tests, the manganese was first added to the flotation cell containing a pH 6.8 phosphate buffer solution. The pyrite was then added and the mixture was allowed to condition for a fixed period of time.

Table 7 shows the results of four of the flotation tests in which manganese powder was added. At pH 6.8, manganese had little effect on pyrite flotation for additions of 0.1 to $0.5 \mathrm{gms}$, although the rejection increased slightly at $\mathrm{pH}$ 4.6. This behavior may indicate that $\mathrm{Mn}(\mathrm{OH})_{2}$ is partially passivated at $\mathrm{pH} 6.8$ and

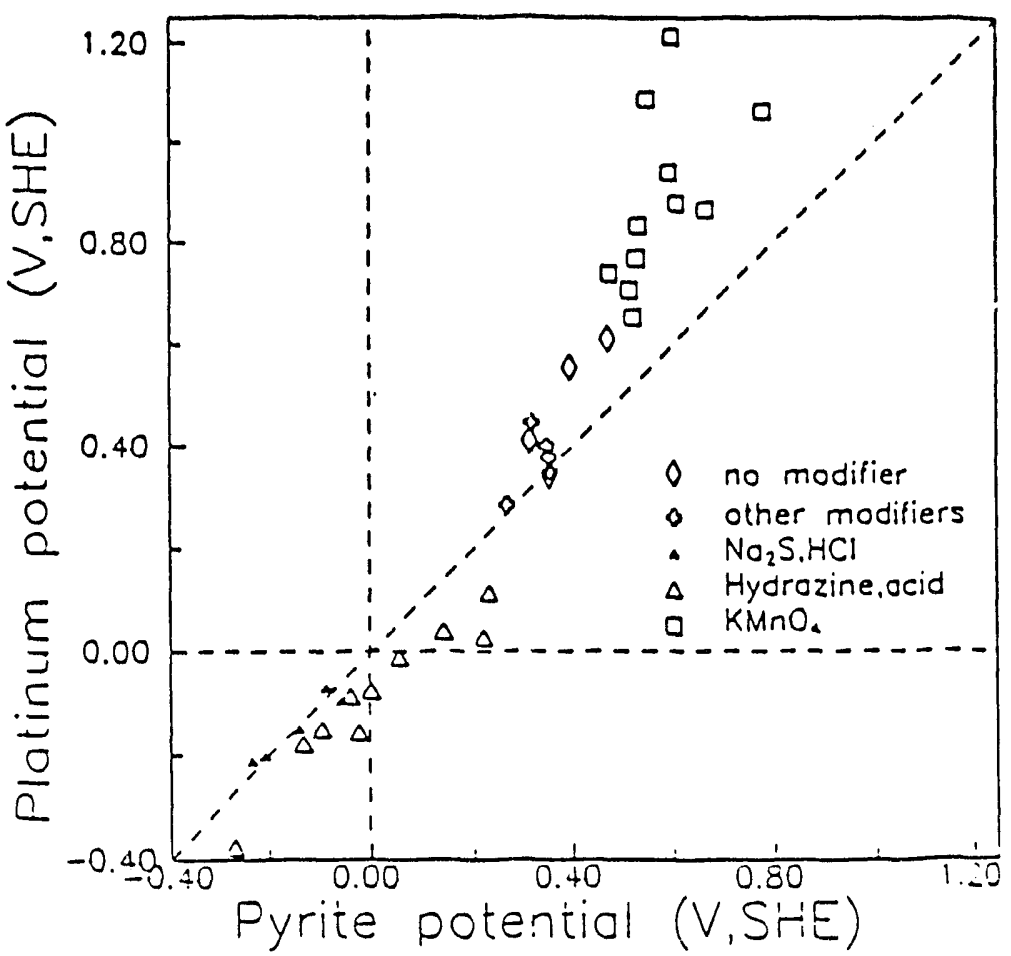

Figure 4: Potential of a bright platinum electrode versus the potential of a mineral pyrite electrode, both inserted into the top of the micro-flotation cell. Hydrazine, permanganate, and sodium sulfide were used to vary the potential. 
the passive film is partly removed at $\mathrm{pH} 4.6$. The table also shows that the redox potential of the solution decreases with an increase in the quantity of manganese in the cell.

Table 7. Microflotation test results for fresh $75 \times 150 \mu \mathrm{m}$ Illinois No. 6 coal pyrite.

\begin{tabular}{||l|l|l|l|l|l||}
\hline $\begin{array}{l}\text { Sample } \\
\text { No. }\end{array}$ & $\mathrm{pH}$ & $\begin{array}{l}\text { Pyrite } \\
\text { Recovery } \\
(\%)\end{array}$ & $\begin{array}{l}\text { Platinum } \\
\text { Potential } \\
\text { (SHE) }\end{array}$ & $\mathrm{Mn}(\mathrm{g})$ & $\begin{array}{l}\text { Conditioning } \\
\text { Time (min) }\end{array}$ \\
\hline \hline 989 & 6.8 & 18.28 & 0.175 & 0 & 15 \\
\hline 988 & 6.8 & 25.34 & -0.205 & 0.1 & 15 \\
\hline 992 & 6.8 & 25.10 & -0.309 & 0.5 & 8 \\
\hline 991 & 4.6 & 15.76 & -0.213 & 0.5 & 15 \\
\hline
\end{tabular}

Subtask 5.3 Galvanic Control Using Sacrificial Anodes

No work was scheduled during this reporting period.

\section{Task 6 - Bench-Scale Testing of the PESR Process}

No work was scheduled during this reporting period.

\section{Task 7 - Modelling and Simulation}

No work was scheduled during this reporting period.

\section{CONCLUSIONS}

1. Ring-disc voltammetry studies on pyrite conducted in the presence of $\mathrm{FeCl}_{2}$ confirm previous conclusions that a soluble ferrous hydroxide product is formed at $\mathrm{pH}$ 9.2. This soluble species is formed both during cathodic scans and during anodic scans. 
2. A combination of ring-disc studies on pyrite with subsequent voltammetry on the gold rings confirm that both soluble iron and soluble sulfur compounds are produced on pyrite electrodes at $\mathrm{pH} 9.2$.

3. Electrochemical studies suggest that the porous nature of Pittsburgh No. 8 coal pyrite may be responsible for the high reactivity of pyrite with regard to its oxidation and reduction behavior. The porosity may also influence the mechanism by which oxygen is reduced at the pyrite surface.

4. Significant differences have been found between the potential of uight platinum electrodes and pyrite electrodes inserted into microflotation cells. The largest potential difference occurs at higher oxidizing potentials. It is believed that pyrite oxidation prevents the pyrite electrode from polarizing to the same extent as platinum.

\section{ACTIVITIES PLANNED FOR NEXT QUARTER}

1. We will perform electrochemical flotation experiments using smaller particles than used in the previous quarter. This will enable us to determine the self-induced flotation in alkaline pH's.

2. The degree of galvanic contact between pyrite and coal, iron, aluminum, and zinc will be determined using a two compartment electrochemical cell.

3. Dynamic electrochemical techniques will be used to study the reaction occurring on pyrite in the microflotation cell. This will be accomplished by inserting a pyrite electrode in the top of a cell and obtaining voltammetry curves under flotation conditions. 

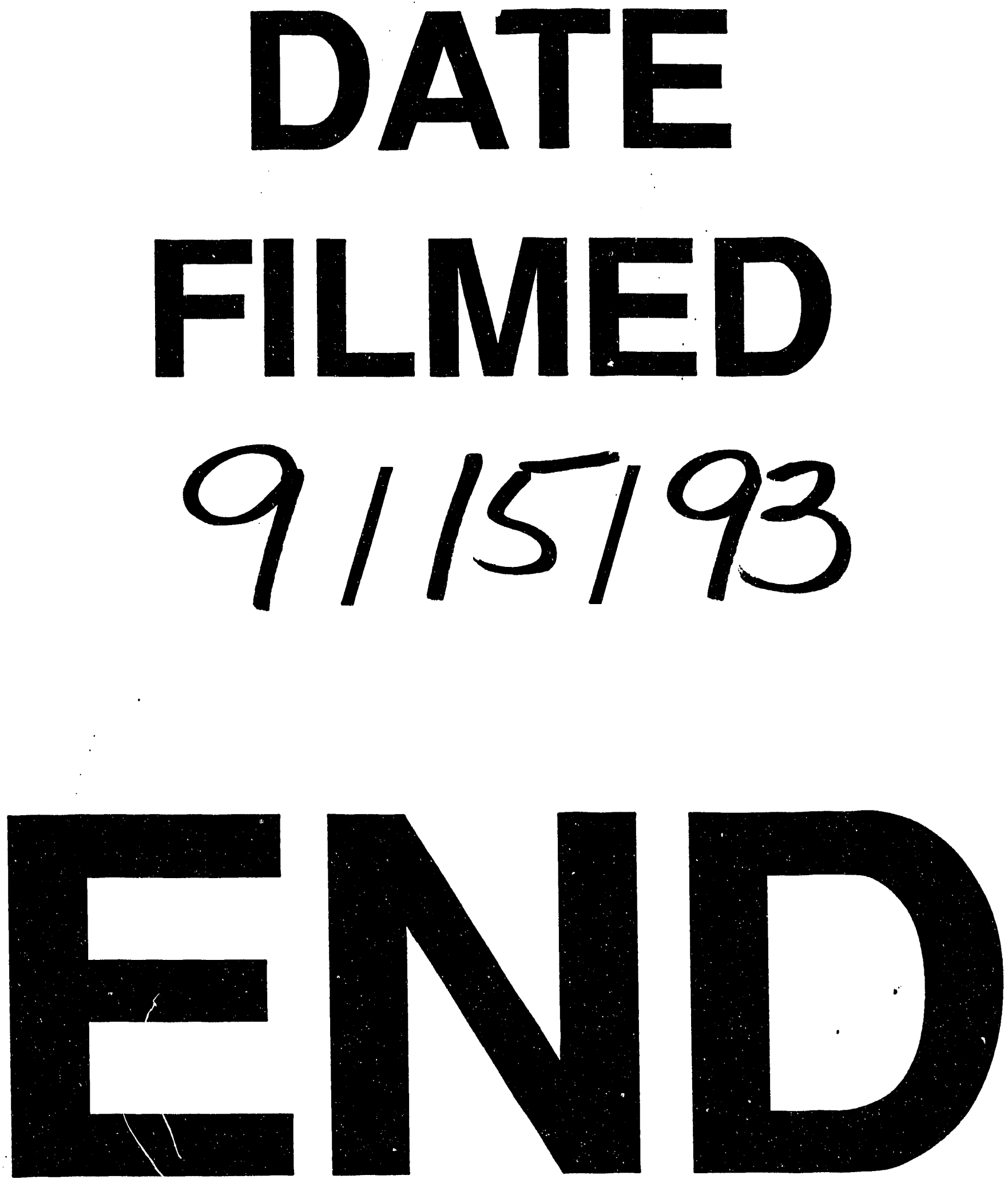
